\title{
NÁHRADA NEMAJETKOVÉ ÚJMY A DALŠÍ PRÁVNÍ VZTAHY ÚČASTI NA PRÁCI
}

\author{
LUCIE MATĚJKA ŘEHOŘOVÁ*
}

\begin{abstract}
Non-pecuniary damages and other employment relationships
The paper analyses different approaches to the issue of non-pecuniary damage compensation in selected other employment relationships, focusing on service relationships. The object of the paper is in particular to point out the substantive and procedural implications of the concept of the non-pecuniary damages and its consequences for the enforcement of the rights of the individual victim.
\end{abstract}

Keywords: non-pecuniary damage; employee; compensation for injury; service relationships

Klíčová slova: nemajetková újma; zaměstnanec; náhrada újmy; služební vztahy

DOI: $10.14712 / 23366478.2019 .9$

\section{ÚVODEM}

Referent na ministerstvu, hasič, policista, voják z povolání, justiční čekatel, advokátní koncipient, úředník územně samosprávného celku, pedagog, zdravotní sestra. To je jen skromný výčet z množiny povolání, jejichž společným jmenovatelem je regulace výkonu závislé činnosti nikoli pouze zákoníkem práce (př́ípadně subsidiárně aplikovatelnými ustanoveními občanského zákoníku) a souvisejícími právními předpisy, ale i jinými právními předpisy, které stojí vedle zákoníku práce (či spíše před zákoníkem práce) a je vůči jeho úpravě v postavení leges specialis. Zmíněné speciální právní předpisy formují více či méně podrobný rámec práv a povinností doplňující základní pracovněprávní úpravu o další soubor závazků reflektujících specifika dané činnosti.

Zákoník práce je základním a obecným právním předpisem pracovního práva, který upravuje právní vztahy vznikající při výkonu závislé práce. Smyslem a účelem pracovněprávních předpisů je prostřednictvím organizačních a ochranných nástrojů regulovat výkon závislé práce zaměstnance pro zaměstnavatele. Jedním z definujících činitelů základních pracovněprávních vztahů je dlouhodobý a kontinuální výkon závislé práce zaměstnance (v organizační podřízenosti) pro zaměstnavatele (v organizační nadříze-

\footnotetext{
* Mgr. Lucie Matějka Řehořová působí na Katedře pracovního práva a práva sociálního zabezpečení Právnické fakulty Univerzity Karlovy jako interní doktorandka a zároveň jako advokátka v Praze.
} 
nosti). Jedná se o osobní vztah založený na vzájemné důvěře obou subjektů, kterým si drtivá většina ekonomicky aktivních lidí obstarává prostředky pro svoji obživu. I přestože je tento typ soukromoprávního vztahu realizovaný ve společnosti masově, ne vždy je zákoník práce a s ním související právní předpisy jediným základním stavebním kamenem pro výkon konkrétní závislé činnosti.

Vedle základní úpravy pracovněprávních vztahů obsažené v zákoníku práce, existují činnosti, které vyžadují specifickou úpravu pro svoji realizaci. Zákoník práce jejich existenci nepř́mo připouští a naznačuje prostřednictvím ustanovení $§ 5$. Doktrínou jsou tyto specifické pracovněprávní vztahy označovány jako „další právní vztahy účasti na práci“" Za účelem identifikace príléhavého souboru konkrétních práv a povinností, které vůči sobě zaměstnanec a zaměstnavatel $\mathrm{v}$ těchto dalších právních vztazích účasti na práci vykonávají, je nezbytné nejprve správně stanovit interpretační pravidla pro podřízení daného právního vztahu těmto normám a určit právní předpis, který se bude na př́slušnou závislou činnost aplikovat. $V$ prípadě úpravy daného právního vztahu speciálním právním předpisem, je zapotřebí dále odpovědně určit jeho vztah a poměr vi̊či zákoníku práce. ${ }^{1}$

Ustanovení § $5 \mathrm{ZP} \mathrm{v}$ tomto kontextu představuje pomyslnou dvoukř́́dlou malovanou skřín z pohádky s tajným vchodem, za kterým se skrývá spletitá a pestrá množina právních vztahů účasti na práci, která má navíc široký potenciál k dalšímu vývoji.

Otázka náhrady nemajetkové újmy v dalších právních vztazích účasti na práci zůstává doposud na okraji zájmu odborné právnické obce, a to i přsestože se týká nemalého počtu zaměstnanců. Jak bude nastíněno v následujících odstavcích, tento určitý zájmový deficit o předmětné téma se zdá být s ohledem na množství otázek, které předmětná právní regulace uvedené oblasti vyvolává, nedůvodný. Předmětem a cílem předkládaného příspěvku je označit a analyzovat jednotlivé systémy náhrady nemajetkové újmy v rámci služebních poměrů a dalších vybraných právních vztahů účasti na práci, které obsahují speciální zákonnou úpravu náhrady nemajetkové újmy. Snahou je zejména poukázat na hmotněprávní a procesní dopady zákonodárcem zvolené koncepce úpravy náhrady nemajetkové újmy a jejich konsekvence při vymáhání práv jednotlivých poškozených.

\section{DALŠÍ PRÁVNÍ VZTAHY ÚČASTI NA PRÁCI - PRAMENY PRÁVNÍ ÚPRAVY}

I přestože se z podoby současné textace dvou odstavců ustanovení § $5 \mathrm{ZP}$ jeví jeho působnost omezená pouze na vztahy vyplývající z výkonu veřejné funkce, historicky bylo toto ustanovení obsáhlejší a jeho široký dosah zůstává prostřednictvím doktrinálního výkladu zachován i nadále.

Za dobu účinnosti zákoníku práce nebylo ani ustanovení § 5 ZP ušetřeno novelizací, z nichž ty nejvýznamnější měly vůči jmenovanému ustanovení vždy derogační účinky, když byly z původních pěti odstavců zachovány do současného znění zákona

1 Nabízí se v zásadě čtyři možnosti vzájemného vztahu mezi zákoníkem práce a speciálním právním předpisem. 1. Vyloučení aplikace zákoníku práce. Speciální předpis bude samostatně aplikovanou normou. Tento př́istup není v souvislosti s dalšími právními vztahy účasti na práci zákonodárcem využíván, když úplné vyloučení zákoníku práce by ve svém důsledku znamenalo nutnost parafrázování většiny ustanovení 
pouze první dva. Novela zákoníku práce provedená zákonem č. 365/2011 Sb., jež byla zákonodárcem prezentována veřejnosti jako jedna z významných koncepčních novel zákoníku práce, zrušila s účinností $\mathrm{k} 1.1 .2012$ v $§ 5$ původní odstavce 4 a 5 , upravující další veřejné funkce (včetně poznámek pod čarou odkazující na příslušné speciální právní předpisy), na jejichž výkon byl aplikován zákoník práce ve vtahu subsidiarity či delegace. ${ }^{2}$ První derogační zásah byl podle důvodové zprávy ${ }^{3}$ uskutečněn s cílem upravit postavení zákoníku práce vůči zvláštním právním předpisům napříště nikoli v pozici jednotné úpravy veškerých pracovněprávních vztahů v České republice, která presumuje vztahy ke zvláštním zákonům, nýbrž jako zákona základního. Zákonodárce přitom vycházel z předpokladu, že ačkoli nebudou právní úpravy odchylné od zákoníku práce výslovně uvedeny v zákoně, nebude to znamenat, že by nadále nemohly být odchylné úpravy pracovněprávních vztahů v jiných zákonech stanoveny. ${ }^{4} \mathrm{~K}$ druhému derogačnímu zásahu do ustanovení $§ 5$ ZP došlo v souvislosti s harmonizací pracovního práva s rekodifikovaným soukromým právem prostřednictvím hlavního změnového předpisu, tedy zákona č. 303/2013 Sb., kterým se mění některé zákony v souvislosti s přijetím rekodifikace soukromého práva. Zákon č. 303/2013 Sb. zrušil s účinností k 1. 1. 2014 v § 5 ZP původní třetí odstavec, upravující subsidiární použití zákoníku práce na pracovní vztahy mezi družstvem a jeho členy. ${ }^{5} \mathrm{Z}$ důvodové zprávy k zákonu č. 303/2013 Sb. vyplývá zrušení třetího odstavce s odkazem na ust. § 579 zákona č. 90/2012 Sb., o obchodních společnostech a družstvech, dle kterého se počítá

zákoníku práce, ačkoliv objektem obou právních vztahů je závislá práce a obsahem pracovní závazek. 2. Př́ímá působnost. Na další právní vztahy účasti na práci se působnost zákoníku práce vztahuje, pokud to zákoník práce výslovně stanoví. 3. Delegace. Působnost zákoníku práce se na další právní vztahy účasti na práci vztahuje, pokud to zvláštní předpisy stanoví. 4. Subsidiarita. Působnost zákoníku práce se na další právní vztahy účasti na práci vztahuje, pokud zvláštní předpis nestanoví jinak.

2 Derogovaný čtvrtý a pátý odstavec ustanovení $§ 5$ ZP ve znění do 31. 12. 2011 (citace provedena bez odkazů na poznámky pod čarou):

„(4) Na pracovněprávní vztahy justičních čekateli̊, státních zástupců, právních čekateli̊ a na zaměstnance vykonávajici ve správních úradech státní správu jako službu, kterou Česká republika poskytuje veřejnosti podle služebního zákona, se tento zákon vztahuje, jen pokud to výslovně stanoví nebo pokud to stanoví zvláštni právni předpisy.

(5) Pracovněprávní vztahy čekateli̊ připravujicích se na výkon státní služby, úředníkủ územních samosprávných celků, akademických pracovníků vysokých škol, pedagogických pracovníkü, řediteli̊ veřejných výzkumných institucí, velitelư plavidel a členů posádek plavidel provozujících námoŕní plavbu, zaměstnanců v Probační a mediační službě, advokátů vykonávajících advokacii v pracovním poměru, asistentů soudců, asistentů státních zástupců, veřejného ochránce práv, zástupce verejného ochránce práv, finančního arbitra, zástupce finančního arbitra, notářských kandidátů, notárských koncipientů, exekutorských kandidátů, exekutorských koncipientů a advokátnich koncipientů se ř́dí tímto zákonem, pokud zvláštní právní předpis nestanoví jinak."

3 Důvodová zpráva k zákonu č. 365/2011 Sb. Parlament České republiky, Poslanecká sněmovna, 6. volební období, 2010-2013, tisk 411/0.

4 Zákoník práce původně převzal úpravu, podle které měl zabezpečovat jednotnou platformu pro pracovněprávní vztahy v České republice s tím, že jakékoli odchylky ve vztahu ke zvláštním zákonům měly být nejenom umožněny, ale zároveň zákonem presumovány. Podle důvodové zprávy se tento přístup nezdál být účelným, nebot' legislativní proces není schopen předpokládat a postihnout všechny možné odchylky a zákonný stav se tak vždy bude opožd'ovat za skutečností.

5 Derogovaný třetí odstavec ustanovení § 5 ZP ve znění do 31. 12. 2014 (citace provedena bez odkazů na poznámky pod čarou): ,(3) Pracovní vztahy mezi družstvem a jeho členy se ř́dí tímto zákonem, nestanoví-li zvláštní právní předpis jinak.“ 
s účinností od 1. 1.2014 jen s pracovním poměrem člena družstva, který bude pro družstvo vykonávat závislou práci. ${ }^{6}$

Mezi speciální právní předpisy upravující další právní vztahy účasti na práci se standardně řadí zákon č. 234/2014 Sb., o státní službě7, zákon č. 361/2003 Sb., o služebním poměru př́slušníků bezpečnostních sborů8 ${ }^{8}$, zákon č. 150/2017 Sb., o zahraniční službě , zákon č. 221/1999 Sb. o vojácích z povolání10, zákon č. 312/2002 Sb., o úřrednících územně samosprávných celků, zákon č. 111/1998 Sb., o vysokých školách, zákon č. 283/1933 Sb., o státním zastupitelství, zákon č. 85/1996 Sb., o advokacii a jiné.

Předmětem komparace a zkoumání v rámci předkládaného př́spěvku bude úprava a zvolený systém náhrady nemajetkové újmy v případě služebních poměrů.

\section{NÁHRADA NEMAJETKOVÉ ÚJMY STÁTNÍHO ZAMĚSTNANCE PODLE ZÁKONA O STÁTNÍ SLUŽBĚ}

První část příspěvku je věnována náhradě nemajetkové újmy státnímu zaměstnanci ve smyslu zákona o státní službě, když služební poměry státních zaměstnanců tvoří nejpočetnější skupinu dalších právních vztahủ účasti na práci co do počtu zúčastněných zaměstnanců.

Zvláštní právní úprava pro zaměstnance státu, resp. veřejné správy je odrazem tradičního př́istupu demokratických zemí $\mathrm{k}$ zaměstnancům činným ve služebním poměru regulovaným zvláštní právní úpravou, která by měla být ovládána zásadami odlišnými od smluvních principů v tržní sfére soukromoprávních pracovněprávních vztahů, a to především prostřednictvím uložení zvýšených povinností státním zaměstnancům za účelem stabilního a profesionálního výkonu veřejné správy. Hlavním smyslem přijetí zvláštní právní úpravy regulující služební poměry státních zaměstnancủ je odpolitizování státní služby tím, že je personálně oddělená od politické moci. ${ }^{11,12}$

Zákon o státní službě reguluje náhradu škody, služební úrazy a nemoci z povolání ve své šesté části, která obsahuje pouze několik delegačních ustanovení odkazujících na příslušnou úpravu zákoníku práce. Př́slušná hmotněprávní pravidla zákoníku práce se

${ }^{6}$ Důvodová zpráva k zákonu č. 303/2013 Sb. Parlament České republiky, Poslanecká sněmovna, 6. volební období, 2010-2013, tisk 930/0.

7 Dále jen „zákon o státní službě“ či „ZSS“.

8 Dále jen „zákon o služebním poměru př́slušníků bezpečnostních sborư“ či „ZSP“.

9 Dále jen „zákon o zahraniční službě“ či „ZZZ“.

10 Dále jen „zákon o vojácích z povoláni““ či „ZVP“.

11 Přestože měly ve svých programových prohlášeních všechny demokratické vlády po sametové revoluci obsažený závazek přijetí zákona o státní službě civilních zaměstnanců, ke konkrétní př́ípravě zákona došlo až v souvislosti s tlakem Evropské unie, která jako jednu z podmínek príijetí České republiky do Evropské unie stanovila príijetí zákona o státní službě. Návrh zákona o službě státních zaměstnancủ ve správních úřadech a o odměňování těchto zaměstnanců a ostatních zaměstnanců ve správních úřadech byl přijat pod č. 218/2002 Sb. jehož účinnost byla nakonec odkládána dvanáct let. Až po hrozbě sankcemi ze strany Evropské unie se zákonodárce $\mathrm{v}$ otázce státní služby přiklonil $\mathrm{k}$ vypracování návrhu nového zákona, který byl přijat pod č. 234/2014 Sb., a který v konečném důsledku politický vliv na státní zaměstnance spíše prohloubil. Uvedené přiléhavě odráží přetrvávající politickou nechut' na jakékoli oficiální, efektivní a funkční úpravě služebních poměrů státních zaměstnanců.

$12 \mathrm{~K}$ tomu srov. PICHRT, Jan a kol. Zákon o státní službě. Komentář. 1. vydání. Praha: Wolters Kluwer, 2015. 
tak v souladu s ust. § 124 zákona o státní službě uplatní i na náhradu nemajetkové újmy způsobené státnímu zaměstnanci.

Nedávný vývoj náhrady nemajetkové újmy v oblasti pracovního práva lze bez nadsázky považovat za mimořádně pestrý. Po účinnosti rekodifikovaného občanského zákoníku byl systém náhrady nemajetkové újmy vzniklé při plnění pracovních úkolů nebo v př́mé souvislosti s ním podroben důkladné revizi. K této revizi nicméně došlo až po bezmála dvou letech účinnosti nového občanského zákoníku, přičemž uvedené prodlení vyvolalo v praxi nemalé problémy. Vzhledem k účinnosti zákona o státní službě jsou veškeré komplikace v pracovněprávní aplikační praxi způsobilé ovlivnit i služební poměry státních zaměstnanců a s ohledem na délku jednotlivých promlčecích lhůt se stále jedná o ,živé“ téma.

Podle ustanovení § 394 odst. 2 zákoníku práce (ve znění do 30. 9. 2015) se do doby nabytí účinnosti právní úpravy úrazového pojištění při odškodňování bolesti a ztíŽení společenského uplatnění postupovalo podle vyhlášky Ministerstva zdravotnictví č. 440/2001 Sb., o odškodnění bolesti a ztížení společenského uplatnění (známá také pod označením „náhradová vyhláška). Její zrušení k 1. 1. 2014 však zamíchalo pracovněprávními kartami, nebot' nebylo jasné, zda podle pravidel již zrušeného právního předpisu nadále nahrazovat újmu způsobenou pracovním úrazem či nemocí z povolání. K nastalé situaci se nikoli nezajímavě vyjádřilo Ministerstvo práce a sociálních věcí, které ke dni 28. 1. 2014 zveřejnilo ve shodě s Ministerstvem zdravotnictví Společné stanovisko k postupu při odškodňování pracovních úrazů a nemocí z povolání po nabytí účinnosti nového občanského zákoníku a kde bylo ve stručnosti konstatováno, že se nadále postupuje podle (v té době již zrušené) náhradové vyhlášky.

Po nabytí účinnosti nového občanského zákoníku jsme tak byli svědci nastalé dvojkolejnosti náhrady nemajetkové újmy, kdy v oblasti občanského práva postupovaly soudy dle vlastního uvážení, resp. podle Metodiky s hodnotou bodu cca 250 Kč, zatímco v oblasti pracovního práva nadále rozhodovaly o výši bolestného a ztížení společenského uplatnění podle náhradové vyhlášky s hodnotou bodu 120 Kč.

Zákonodárce konečně přistoupil k řešení otázky náhrady újmy způsobené pracovním úrazem a nemocí z povolání prostřednictvím novely zákoníku práce provedené zákonem č. 250/2015 Sb., která nabyla účinnosti k 1. 10. 2015. Novela mimo jiné definitivně upřednostnila náhradu nemajetkové újmy vzniklé v pracovněprávních vztazích v rámci soukromého práva, když zrušila zákon o úrazovém pojištění a zmocnila vládu, aby nařízením stanovila výši náhrady za bolest a ztížení společenského uplatnění odpovídající vzniklé újmě. Zákoník práce tak uzavřel pomyslný kruh způsobu stanovení výše náhrady za újmu na zdraví v soukromém právu, když se znovu navrátil ke stanovení výše náhrady za újmu na zdraví podzákonným předpisem vyšlým z pera moci výkonné, ačkoli je tento přístup v přímém rozporu s důvodovou zprávou nového občanského zákoníku.

Přijaté nařizení vlády č. 276/2015 Sb., o odškodňování bolesti a ztížení společenského uplatnění způsobené pracovním úrazem nebo nemocí z povolání (dále jen „nařízení“) vešlo v účinnost ke dni 26. 10. 2015. Nařízení vychází obdobně jako Metodika Nejvyššího soudu k náhradě nemajetkové újmy na zdraví a náhradová vyhláška z bodového hodnocení. Počty bodů pro hodnocení bolesti a ztížení společenského uplatnění způsobené pracovním úrazem a nemocí z povolání jsou uvedeny celkem ve čtyřech 
přílohách. Od Metodiky se nařízení (bez jakéhokoli bližšího odůvodnění) liší jednak fixní hodnotou jednoho bodu, která je stanovena na 250 Kč, a zároveň způsobem výpočtu náhrady ztížení společenského uplatnění, který v Metodice nově vychází z konceptu ztráty životních př́iležitostí, zatímco nařízení si nadále vystačí s bodovým hodnocením.

Zákoník práce $\mathrm{v}$ novelizovaném znění přiznává $\mathrm{v}$ př́ípadě smrti zaměstnance právo pozi̊stalých na jednorázové odškodnění, konkrétně manželovi, partnerovi a nezaopatřenému dítěti, a to každému ve výši nejméně 240.000 Kč. Jednorázové odškodnění př́ísluši i rodičům zaměstnance, pokud s ním žili v domácnosti, a to v úhrnné výši nejméně 240.000 Kč. Oproti úpravě občanskoprávní je pracovněprávní úprava jednorázového odškodnění nedůvodně restriktivnější, a to především co do okruhu oprávněných. Dítě je oprávněným pouze, pokud splňuje podmínku nezaopatřenosti, rodiče musí splnit podmínku společné domácnosti a zákoník práce vůbec nepočítá s odčiněním újmy osoby blízké.

Přestože služební zákon odkazuje na úpravu náhrady nemajetkové újmy zaměstnance, není ani tato delegace s ohledem na existující otázky a často nedůvodné rozdíly pracovněprávní a občanskoprávní úpravy samospásná. Ačkoli již nejsou rozdíly mezi systémem náhrady újmy založeným obecnou úpravou občanskoprávní a úpravou pracovněprávní tak markantní jako dříve, dvojkolejnost nadále pokračuje. Ústavní soud shledal nařízení problematickým zejména tím, že nerespektuje přinejmenším ve vztahu k odčinění ztížení společenského uplatnění systém stanovení náhrad podle Metodiky, ale především opomíjí premisu rekodifikovaného civilního soukromého práva, totiž že rozhodovací činnost soudů při stanovení konkrétních částek odčinění je třeba oprostit od vlivu moci výkonné, která není oprávněna limitovat soudy v přiznání spravedlivé a dostatečné náhrady.

Z výše uvedeného je patrné, že hmotněprávní úprava zákoníku práce týkající se odčinění nemajetkové újmy vzniklé v souvislosti s výkonem závislé práce vyvolává řadu otázek, na které by mohla poskytnout odpověd’ budoucí relevantní judikatura. Budou-li nicméně mít soudy vůli určitým způsobem sjednotit náhradu nemajetkové újmy v rámci civilního práva, nezbude jim nic jiného, než opětovně aktivovat čl. 95 odst. 2 Ústavy, který jediný jim v současné chvíli v pracovněprávních sporech otevírá cestu k volné úvaze při určování výše náhrady za nemajetkovou újmu.

Zatímco v oblasti soukromoprávní náhrady nemateriální újmy lze za neutěšenou považovat otázku hmotněprávní (tj. ,kolik“ bude plněno), procesní stránka věci zůstává stabilní, nebot' př́slušný bude k rozhodování o př́ípadném sporu obecný soud žalovaného a řízení bude vedeno podle pravidel zákona č. 99/1963 Sb., občanský soudní řád. V př́padě odpovědnostních nároků souvisejících se státní službou je kontroverzní jak otázka hmotněprávní (,kolik“ bude plněno), což je dáno prímou vazbou na zákoník práce, tak i otázka procesní (tj. „kdo“ je orgánem př́slušným k rozhodování o př́ípadných sporech).

V souvislosti s analýzou úpravy nemajetkové újmy v rámci služebních vztahů si nelze odpustit drobnou poznámku stran terminologie použité $\mathrm{v}$ zákoně o státní službě. Novela zákoníku práce provedená zákonem č. 205/2015 Sb. přizpůsobila s účinností k 1. 10. 2015 dosavadní terminologii obsaženou v části jedenácté zákoníku práce, která upravovala náhradu škody, pojmosloví užívanému v novém občanském zákoníku. Na- 
dále se tedy nehovoří o „náhradě škody“, ale o „náhradě škody a nemajetkové újmy“ a termín „odpovědnost za škodu“ byl nahrazen „,povinností k náhradě škody“. Uvedené však nebylo v zákoně o státní službě nijak reflektováno. Logickým výkladem je nutné dojít k závěru, že pokud zákon o státní službě používá pouze termín „škoda“ a současně odkazuje na úpravu v zákoníku práce, škodou dle zákona o státní službě nemůže být myšlena pouze majetková újma (ve smyslu legislativní zkratky uvedené v ust. § 249 odst. 1 zákoníku práce), ale rovněž újma nemajetková. $Z$ uvedených důvodů je nutné „odpovědnost za škodu“ dle zákona o státní službě vykládat jako „povinnost k náhradě škody a nemajetkové újmy“ ve smyslu obecného civilistického pojmosloví, se kterým bude níže $\mathrm{v}$ textu pracováno.

Klíčovou otázkou, která v souvislosti s problematikou povinnosti k náhradě újmy podle části šesté zákona o státní službě vyvstala, je otázka povahy odpovědnostního vztahu odvislého od výkonu služby. Pro účely překládaného př́íspěvku bude níže analyzována pouze dílčí část odpovědnostních vztahů souvisejících s výkonem služby, a to povinnost služebního úřadu $\mathrm{k}$ náhradě nemajetkové újmy při pracovním úrazu či nemoci z povolání státního zaměstnance. Stran povahy uvedeného vztahu existují dva protichůdné názory implikující dvě varianty řešení:

1. Rozhodování o povinnosti k náhradě újmy na straně státního zaměstnance je jedním z druhů rízení ve věcech služby, tj. zvláštního správního řízení, nebot' ačkoli se jedná o odpovědnostní vztah mezi služebním úruadem a státním zaměstnancem, rozhoduje se ve věci služebního poměru;

2. Povinnost k náhradě újmy v rámci zákona o státní službě s ohledem na př́mý odkaz na zákoník práce má být rozhodována pouze $\mathrm{v}$ soukromoprávním režimu a př́ípadné spory z těchto vztahů vzniklé mají být řešeny před civilním soudem.

Zákon o státní službě obsahuje v ust. § 159 odst. 1 výčet rozhodnutí, na která se vztahují ustanovení o rrízení ve věcech služby, přičemž rozhodování o povinnosti k náhradě škody a nemajetkové újmy není v tomto výčtu uvedeno. V následujícím odstavci ust. § 159 zákona o státní službě jsou naopak vymezena rozhodnutí, na která se režim řízení ve věcech státní služby nevztahuje; odpovědnostní vztahy však nejsou uvedeny ani zde. ${ }^{13}$ Tato nedůslednost zákonodárce a mezera v zákoně má významné procesní důsledky.

I přestože vytváří ust. § 159 zákona o státní službě zdání, že oba jeho odstavce obsahují taxativní výčty rozhodnutí, stále silněji byly po přijetí zákona o státní službě slyšet hlasy, podle kterých by měly být odpovědnostní vztahy uznány pod věci služebního poměru, tzn. variantu 1 .

Režimem projednání povinnosti nahradit škodu způsobenou státním zaměstnancem služebnímu úřadu a způsobenou služebním úřadem státnímu zaměstnanci se zabýval Poradní sbor náměstka ministra vnitra pro státní službu, který na svém zasedání dne 3. června 2016 dospěl k závěru, že proces rozhodování o odpovědnosti státního zaměst-

13 Nutno v této souvislosti poznamenat, že formulace, která zakazuje použití ustanovení správního rádu o správním rrízení na rozhodování o vyjmenovaných záležitostech státní služby, nevylučuje použití správního řádu jako takového, ale pouze jeho druhou a třetí část („Obecná ustanovení o správním řízení“ a „Zvláštní ustanovení o správním řízeni““). Vykonává-li správní orgán působnost v oblasti veřejné správy, vztahuje se na jeho postupy správní řád alespoň v části základních zásad činnosti správních orgánů. 
nance nebo služebního úřadu za škodu nebo nemajetkovou újmu podle části šesté zákona o státní službě, je jedním z druhů řízení ve věcech služby. Inspirací mu přitom byla mimo jiné rovněž úprava zákona o služebním poměru př́slušníků bezpečnostních sborů, dle kterého je rozhodování o náhradě škody podřazeno pod režim řízení ve věcech služebního poměru. Podle uvedeného závěru pravomoc rozhodovat o náhradě škody a nemajetkové újmy nemůže být služebním orgánem přenesena na jiné představené, přičemž jiné úkony v řízení mohou ve smyslu ust. § 15 odst. 2 správního řádu provádět úřední osoby $\mathrm{k}$ tomu oprávněné podle služebních předpisů nebo $\mathrm{k}$ tomu pověřené služebním orgánem. ${ }^{14}$

V této souvislosti není bez zajímavosti, že historicky byl vztah právní úpravy řízení ve věcech služebního poměru a obecné úpravy správního řízení jiný, když tehdejší vládní nařízení č. 8/1928 Sb., o řízení ve věcech náležejících do působnosti politických úřadů (správní ř́zení), výslovně ve svém ust. § 1 odst. 2 stanovilo, že se úprava tohoto správního řádu nevztahuje na řízení ve věcech služebního poměru státních zaměstnanců; a ani pozdějšš správní řád se na rozhodování ve věcech služebního poměru, které bylo chápáno jako rozhodování $\mathrm{v}$ jeho interních vztazích nadřízenosti a podřizenosti, nevztahovaly. ${ }^{15}$

Ke zvolenému způsobu a dovozování režimu použitelného na oblast náhrady škody a nemajetkové újmy podle zákona o státní službě lze na tomto místě pouze dodat, že by se s ohledem na právní jistotu adresátů právních norem a jejich potřebnou legitimitu slušelo reflektovat a napravit nalezenou mezeru zákona př́slušnou novelizací, která by doplnila ust. § 159 odst. 1 zákona o státní službě o bod zahrnující oblast náhrady škody. Postavení Poradního sboru náměstka ministra vnitra pro státní službu, povaha a závaznost jeho závěrů pro adresáty právní normy jsou přinejmenším diskutabilní. ${ }^{16}$

V př́ípadě subsumpce odpovědnostních vztahů pod věci služebního poměru, bude o nárocích z nemajetkové újmy státního zaměstnance rozhodovat služební orgán a odkaz ust. § 124 zákona o státní službě na zákoník práce bude fungovat výlučně jako hmotněprávní.

Takové ř́zení bude vedeno podle procesních ustanovení zákona o státní službě, přičemž se v souladu s ust. § 160 zákona o státní službě bude subsidiárně postupovat podle zákona č. 500/2004 Sb., správní rád (dále jen „správní řád“).

Porovnáme-li v základních aspektech rozhodování o náhradě nemajetkové újmy zaměstnance a státního zaměstnance, lze dojít $\mathrm{k}$ následujícím závěrům. $\mathrm{V}$ případě zaměstnance bude o výši náhrady nemajetkové újmy (bolestné, náhrada za ztížení společenského uplatnění aj.) rozhodovat civilní soudce, který disponuje př́slušnou autoritou, je nezávislý a nestranný a tato nezávislost a nestrannost je garantována několika

14 Závěr č. 5 ze zasedání poradního sboru náměstka ministra vnitra pro státní službu k zákonu o státní službě ze dne 3. června 2016.

$15 \mathrm{~K}$ tomu více KOPECKÝ, M. In: PICHRT, J. a kol. Zákon o státní službě. Komentářr. 1. vyd. Praha: Wolters Kluwer, 2015.

16 V českém právním řádu bohužel není tento typ „dotváření zákonư“ mocí výkonnou ojedinělý. Vzpomeňme např́íklad na Společné stanovisko Ministerstva práce a sociálních věcí a Ministerstva zdravotnictví ze dne 28. 1.2014 k postupu při odškodňování pracovních úrazů a nemocí z povolání po nabytí účinnosti nového občanského zákoníku, ve kterém bylo ve dvou odstavcích konstatováno, že se nadále postupuje podle (v té době již zrušené) náhradové vyhlášky. 
ústavněprávními instrumenty, je vázaný pouze zákonem a mezinárodní smlouvou ve smyslu čl. 95 Ústavy, má vysokoškolské právní vzdělání, justiční zkoušku a stojí za ním rozsáhlá judikatura; řízení bude ovládáno zásadou dispoziční, zásadou veřejnosti, principem rovnosti a právem na spravedlivý proces. Naproti tomu v př́padě státního zaměstnance bude o výši náhrady nemajetkové újmy (bolestné, náhrada za ztížení společenského uplatnění aj.) rozhodovat služební orgán, na jehož profesní postavení nejsou kladeny ani zdaleka takové nároky jako na soudce. Služební orgán zastupuje v uvedeném řízení služební úřad, což převedeno do vztahů pracovněprávních je obdobné, jako by o výši náhrady nemajetkové újmy zaměstnavatele rozhodoval zaměstnavatel sám. Správní ŕízení bude vedeno zásadou legality a oficiality, zásadou písemnosti, zásadou vyhledávací, zásadou ochrany veřejného a jiného obecného zájmu a v neposlední řadě zásadou neveřejnosti, která ve správních řízeních převažuje.

Řízení o náhradě nemajetkové újmy bude v souladu s principy správního řízení zahajováno z moci úřední, tzn. jakmile se služební orgán dozví o tom, že jsou zde důvody k zahájení rízení. V prípadě nečinnosti služebního orgánu lze postupovat dle úpravy ust. $\S 80$ odst. 2 správního řádu a pravidel ochrany před nečinností. Domáháli se zahájení rízení státní zaměstnanec, je třeba na jeho podání hledět jako na podnět k zahájení rízení ve smyslu ust. § 42 správního řádu. Není vyloučeno, aby ještě před zahájením řízení o náhradě škody došlo k projednání nároků státního zaměstnance (před př́slušnou škodní komisí či mimo ni), jehož výsledkem by mohlo být uzavření dohody o výši škody a způsobu její úhrady. Tato dohoda by s ohledem na ust. § 161 odst. 1 správního řádu splňovala podmínky uzavření veřejnoprávní smlouvy.

Postoupíme-li o pár procesních kroků ve správním řízení vpřed, má státní zaměstnanec právo odvolat se proti rozhodnutí služebního orgánu k nadřízenému služebnímu orgánu. Proti rozhodnutí nadřízeného služebního orgánu bude jako opravný prostředek připadat $\mathrm{v}$ úvahu žaloba proti rozhodnutí správního orgánu ve smyslu ust. § 65 a násl. zákona č. 150/2002 Sb., soudní rád správní17, kdy teprve tehdy se věc dostane k rukám profesionálního soudce. Délka soudních řízení je obecně v České republice velmi vysoká a předcházející správní řízení státnímu zaměstnanci jeho čekání na přiznanou náhradu nemajetkové újmy jistě neukrátí.

Za nejproblematičtější lze však, v případě akceptování konceptu rozhodování o náhradě nemajetkové újmy v intencích správního rrízení, považovat roli správního soudu, která vychází a je poplatná zcela odlišným principům správního soudnictví od soudnictví civilního. Předmětem rozhodování služebního orgánu je konkrétní částka, která bude státnímu zaměstnanci služebním úřadem vyplacena v souvislosti s jeho utrpěným služebním úrazem či nemocí z povolání. Hmotněprávně bude služební orgán nucen aplikovat pravidla zákoníku práce, resp. nařízení vlády č. 276/2015 Sb., o odškodňování bolesti a ztížení společenského uplatnění způsobené pracovním úrazem nebo nemocí z povolání. Částka, ke které služební orgán dojde, je pro státního zaměstnance částkou finální. Správní soud nemá moderační právo a nemůže částku, kterou služební orgán přiznal jakkoli měnit. Primárním účelem správního soudnictví není nalézání práva, ale pouze soudní kontrola veřejné správy, tj. kontrola legitimity a legality rozhodnutí slu-

17 Dále jen „soudní řád správní“ či „SŘS“. 
žebního orgánu. Podstatou řízení o náhradu nemajetkové újmy však není nic jiného než nalézání práva státního zaměstnance na konkrétní výši náhrady. S ohledem na rozsah tohoto př́íspěvku navíc pomineme absurdní důsledky, ke kterým může dojít $\mathrm{v}$ případě aplikace ust. $\S 165$ zákona o státní službě, podle něhož může být vydání rozhodnutí prvním úkonem v řízení.

\section{NÁHRADA NEMAJETKOVÉ ÚJMY PŘÍSLUŠNÍKA BEZPEČNOSTNÍCH SBORU゚ PODLE ZÁKONA O SLUŽEBNÍM POMĚRU PŘÍSLUŠNÍKŮ BEZPEČNOSTNÍCH SBORŮ}

Následující část př́spěvku je věnována náhradě nemajetkové újmy podle zákona o služebním poměru př́íslušníků bezpečnostních sborů, kde bude opět hlavní pozornost věnována povinnosti bezpečnostního sboru $\mathrm{k}$ náhradě škody a nemajetkové újmy vzniklé př́islušníkovi služebním úrazem či nemocí z povolání.

Zákon o služebním poměru př́slušníků bezpečnostních sborů upravuje vztahy vyplývající a související se služebním poměrem komplexně a marně bychom $\mathrm{v}$ jeho textu hledali jakýkoli odkaz na zákoník práce či správní ráa. Nejvyšší správní soud nicméně ve své rozhodovací praxi dovodil, že přestože zákon vztah úpravy o řízení ve věcech služebního poměru ke správnímu rrádu zákon neřeší, obecná úprava správního řízení podle správního řádu se použije subsidiárně i na řízení ve věcech služebního poměru př́slušníků bezpečnostních sborů, nebot' použití obecné úpravy není zákonem vyloučeno. ${ }^{18}$

Odpovědnostní vztahy odvislé od služebního poměru upravuje zákon v části sedmé, prričemž ohledně terminologie platí to samé, co bylo výše uvedeno u zákona o státní službě, terminologie nekoresponduje s novým soukromým právem, nicméně pro zachování přehlednosti a celistvosti textu bude nadále pracováno s rekodifikovaným pojmoslovím.

Úprava povinnosti k náhradě škody a nemajetkové újmy v zákoně o služebním poměru př́ślušníků bezpečnostních sborů relativně koresponduje s úpravou v zákoníku práce. $\mathrm{V}$ př́padě bolesti a ztížení společenského uplatnění má př́slušník nárok na jednorázovou náhradu, jejíž výši stanoví v souladu se zákonným zmocněním v ust. § 104 odst. 2 vyhláškou Ministerstvo vnitra v dohodě s Ministerstvem financí, Ministerstvem spravedlnosti a zpravodajskými službami. Vyhláška č. 277/2015 Sb., o postupu při určování výše náhrady za bolest a za ztížení společenského uplatnění př́slušníků bezpečnostních sborů, byla prrijata 26. 10. 2015 a je poslední vyhláškou provádějící uvedené ustanovení zákona. Při srovnání zmíněné vyhlášky a nařízení vlády č. 276/2015 Sb., o odškodňování bolesti a ztížení společenského uplatnění způsobené pracovním úrazem nebo nemocí z povolání, které provádí totožnou oblast zákoníku práce, je patrné, že byly obě úpravy přijaty současně a ve způsobu výpočtu odčinění za bolest a ztížení společenského uplatnění se zcela shodují. Vyhláška také vychází z bodového systému

18 K tomu srov. Rozsudek Nejvyššího správního soudu ze dne 22. ledna 2014, sp. zn.: 3 Ads 117/2012. 
jak pro účely odčinění bolestného, tak i pro odčinění ztížení společenského uplatnění. Hodnota bodu je stanovena fixní částkou 250 Kč. ${ }^{19}$

Jednorázové odškodnění pozůstalých se v souladu s ust. § 109 odst. 1 zákona o služebním poměru příslušníků bezpečnostních sborů v případě smrti př́slušníka poskytne pozůstalému manželovi př́slušníka a nezaopatřenému dítěti, a to každému ve výši 400000 Kč, a každému rodiči příslušníka, jestliže s ním žil v domácnosti, ve výši 240000 Kč. Je patrné, že okruh oprávněných osob je v porovnání s okruhem oprávněných osob stanovených $\mathrm{v}$ zákoníku práce, jehož ustanovení se použijí pro služební poměr státních zaměstnanců, užšíi ${ }^{20}$, nicméně co do své výše odškodnění téměř dvojnásobně přesahuje výši jednorázového odškodnění stanoveného v ust. § 271i odst. 1 zákoníku práce. Orgán př́slušný k rozhodnutí o výši jednorázového odškodnění zde sice nemá, na rozdíl od občanskoprávní či pracovněprávní úpravy možnost úvahy, nebot' částky jednorázového odškodnění pozůstalých jsou stanoveny fixně bez ohledu na konkrétní okolnosti případu, nicméně zákon o služebním poměru příslušníků bezpečnostních sborů obsahuje v ust. § 109 odst. 2 valorizační formuli, která ukládá jednorázové odškodnění pozůstalých každoročně zvýšit v poměru k navýšení průměrné měsíční mzdy v nepodnikatelské sféře dosažené podle zveřejněných údajů Českého statistického úrúadu za předminulý kalendářní rok.

Stejně jako zákoník práce i zákon o služebním poměru př́slušníků bezpečnostních sborů výslovně obsahuje zvláštní úpravu odpovědnosti bezpečnostního sboru za jinou škodu na zdraví př́slušníka, než je škoda vzniklá služebním úrazem nebo nemocí z povolání. Pro způsob a rozsah náhrady platí ustanovení o služebním úrazu s tím omezením, že nevzniká nárok na jednorázové odškodnění a jednorázové odškodnění pozůstalých.

Rozhodování ve věcech náhrady škody týkající se příslušníkủ bezpečnostních sborů je podřazeno pod režim řízení ve věcech služebního poměru. ${ }^{21}$ Zákon o služebním poměru př́slušníků bezpečnostních sborů v ust. § 171 stanoví pouze negativní výčet druhů rozhodnutí, v nichž se nevede řízení ve věcech služebního poměru, a contrario proto o věcech $\mathrm{v}$ tomto ustanovení neuvedených, mezi které patří i odpovědnostní vztahy, rozhoduje služební funkcionář.

Řízení ve věcech služebního poměru upravuje zákon v ust. § 169 a násl. komplexně. Řízení je zahájeno na žádost účastníka nebo z podnětu bezpečnostního sboru dnem, kdy je žádost účastníka doručena věcně př́slušnému služebnímu funkcionáři, nebo služební funkcionář učiní první úkon vi̊či účastníku, jestliže se zahajuje řízení z podnětu bezpečnostního sboru. V otázce jednotlivých limitů a rizik řízení platí obdobné, co bylo řečeno výše u řízení ve věcech služebních poměrů státních zaměstnanců.

19 K tomu srov. ust. § 7 odst. 2 vyhlášky č. 277/2015 Sb., o postupu při určování výše náhrady za bolest a za ztížení společenského uplatnění př́islušníků bezpečnostních sborů.

20 Okruh pozůstalých oprávněných $\mathrm{k}$ jednorázovému odškodnění pro př́ípad smrti př́islušníka nepamatuje na rozdíl od pracovněprávní úpravy na registrovaného partnera př́slušníka.

21 K tomu srov. Rozsudek Nejvyššího správního soudu ze dne 10. července 2013, sp. zn.: 4 Ads 2/2013. 


\section{NÁHRADA NEMAJETKOVÉ ÚJMY PODLE ZÁKONA O ZAHRANIČNÍ SLUŽBĚ}

Jako tzv. ,ještě teplý، bychom mohli označit zákon o zahraniční službě, který byl do českého právního řádu přijat poměrně nedávno. Tento zákon má plnit funkci základního právního předpisu, který uceleným způsobem vymezí na jedné straně základní pravidla a zásady výkonu zahraniční služby jako specifické činnosti státní správy, a dále nastaví zvláštní pravidla pro vnitřní organizaci státní služby vykonávané v Ministerstvu zahraničních věcí, zohledňující specifický charakter služby, resp. práce vykonávané v rámci zahraniční služby. Účelem zákona je zajistit nezbytnou právní úpravu zahraniční služby jako státní služby sui generis a vytvořit základní předpoklady pro její optimální výkon. Jedním z cílů zákona o státní službě bylo zvýšení právní jistoty státních zaměstnanců a zaměstnanců vykonávajících zahraniční službu, včetně možnosti profesionálního růstu, a dále umožnění nastavení stabilních podmínek v rámci Ministerstva zahraničních věcí pro řádné fungování zahraniční služby. ${ }^{22}$

Vztah k dalším právním předpisům upravuje zákon o zahraniční službě, když ve svém ust. $§ 58$ odst. 1 stanoví subsidiární působnost zákona o státní službě pro služební vztahy upravené zákonem o zahraniční službě a subsidiární působnosti zákoníku práce pro pracovněprávní vztahy upravené v zákoně o státní službě. V obou př́ípadech lze konstatovat, že hmotněprávní těžiště právní úpravy náhrady nemajetkové újmy bude s ohledem na delegační princip zakotvený v zákoně o státní službě, ležet v části jedenácté zákoníku práce.

Speciální úpravu stanoví zákon o zahraniční službě v oblasti náhrady nemajetkové újmy pro př́ípad přiznání invalidního důchodu diplomatickému, administrativnímu nebo technickému pracovníkovi, který vykonával službu nebo práci v zahraničí. V př́ípadě invalidity prvního nebo druhého stupně, ke které došlo v důsledku mimořádné události či trestného činu v přijímajícím státě, přiznává zákon jednorázové odškodnění ve výši šestinásobku průměrného měsíčního platu pracovníka; v prŕípadě přiznání invalidního důchodu pro invaliditu třetího stupně náleží takovému pracovníkovi jednorázové odškodnění ve výši desetinásobku průměrného měsíčního platu pracovníka. Totožný nárok má člen rodiny, který diplomatického, administrativního nebo technického pracovníka doprovází.

Zákon o zahraniční službě dále přiznává jednorázové odškodnění pozůstalému manželovi, partnerovi a nezaopatřenému dítěti, a to každému ve výši dvacetinásobku průměrného měsíčního platu diplomatického, administrativního nebo technického pracovníka $\mathrm{v}$ případě jeho úmrtí, které nastalo $\mathrm{v}$ důsledku mimořádné události nebo trestného činu v zahraničí. ${ }^{23}$

22 Podrobněji ohledně okolnosti, důvodů a cílů zákona v Důvodové zprávě k zákonu č. 150/2017 Sb. Parlament České republiky, Poslanecká sněmovna, 7. volební období, 2013-2017, tisk 994/0.

23 Důvodová zpráva k zákonu o zahraniční službě uvádí, že Ministerstvo zahraničních věcí vyplácí náhradu nákladů na výživu pozůstalých v důsledku vedoucího zastupitelského úřadu, který se stal obětí teroristického činu, celkem 270000 Kč ročně. Zákon o zahraniční službě by pro tento př́ípad přiznal pozůstalým rovněž jednorázové odškodnění ve výši dvacetinásobku průměrného měsíčního platu, které by s ohledem na zařazení vedoucího zastupitelského úřadu v nejvyšším platovém stupni 15. platové tř́idy činilo 743200 Kč. 


\section{ZÁVĚREM}

Cílem tohoto prríspěvku bylo nastínit jednotlivé př́stupy k problematice náhrady nemajetkové újmy $\mathrm{v}$ rámci vybraných dalších právních vztahů účasti na práci, se zaměřením na služební vztahy. V této souvislosti je znovu nutné zdůraznit, že oblasti náhrady nemajetkové újmy by v rámci zvýšení systematičnosti a přehlednější orientaci v př́slušných právních předpisech, slušelo určité sjednocení, alespoň v podzákonných právních předpisech, když vyhláška č. 277/2015 Sb., o postupu při určování výše náhrady za bolest a za ztížení společenského uplatnění př́slušníkủ bezpečnostních sborů spolu s nařízením vlády č. 276/2015 Sb., o odškodňování bolesti a ztížení společenského uplatnění způsobené pracovním úrazem nebo nemocí z povolání, obsahují zcela identické obodování jednotlivých zranění při určování výše bolestného a ztížení společenského uplatnění.

Rozpory mezi jednotlivými systémy náhrad nemajetkové újmy, na které prŕspěvek upozornil, jsou o to bizarnější, pokud si uvědomíme, že jak v př́ípadě nemajetkové újmy zaměstnance, tak v př́ipadě nemajetkové újmy státního zaměstnance, se jedná o vztahy odvozené od výkonu závislé práce. To vše při vědomí, že stejným jmenovatelem v každém systému náhrady nemajetkové újmy zůstává určení hodnoty zdraví konkrétního člověka.

Mgr. Lucie Matějka Řehořová

Právnická fakulta Univerzity Karlovy

lucie.rehorova@seznam.cz 